LEDIG, F. T. (1987): Genetic structure and the conservation of California's endemic and near endemic conifers, pp. 587-594. In: Conservation and management of rare and endangered plants, edited by T. S. ELLIS, California Native Plant Society, Sacramento.

LEINONEN, I. and H. HÄNNINEN (2002): Adaptation of timing of bud burst of Norway spruce and boreal climates. Silva Fennica 36: 695-701.

MARACCHI, G., O. SiRotenko and M. Bindi (2005): Impacts of present and future climate variability on agriculture and forestry in the temperate regions: Europe. Climatic Change 70: 117-135.

MÁTYÁs, C. (1996): Climatic adaptation of trees: rediscovering provenance tests. Euphytica 92: 45-54.

PARMESAN, C. and G. Yohe (2003): A globally coherent fingerprint of climate change impacts across natural systems. Nature 421: 37-42.

Root, T. L., J. T. Price, K. R. Hall, S. H. Schneider, C. Rosenzweig and J. A. Pounds (2003): Fingerprints of global warming on wild animals and plants. Nature 421: 57-60.

SAS InstituTE INC. (1990): SAS/STAT(c) User's Guide, Version $6,4^{\text {th }}$ edition. Cary.

Searle, S. R., G. Casella and C. E. McCulloch (1992): Variance components. John Wiley \& Sons, New York.

SogAard, G., O. Johnson, J. Nilsen and O. Junttila (2008): Climatic control of bud burst in young seedlings of nine provenances of Norway spruce. Tree Physiology 28: $311-320$.

Spencer, D. (2001): Conifers in the Dry Country: A report for the RIRDC/L\&W Australia/FWPRDC Joint Venture Agroforestry Program. CSIRO Forestry and Forest Products-Australia, RIRDC Publication No: 01/46, Australia, $60 \mathrm{p}$.
SpitTlehouse, D. L. (2005): Integrating climate change adaptation into forest management. Forestry Chronicle 81: 691-695.

StONECyPheR, R. W. (1992): Computational methods, pp. 195-228. In: Handbook of quantitative forest genetics edited by L. Fins, S. T. Friedman and J. V. BRotschol, Kluwer Academic Publishers, Dordrecht, the Netherlands.

Swallow, W. H. and J. F. Monahan (1984): Monte Carlo comparison of ANOVA, MIVQUE, REML, and ML estimators of variance components. Technometrics 26: 47-57.

VelioĞLU, E., F. F. ÇiçEK, Z. KAYA and B. ÇENGEL (2000): Genetic variation in natural Kazdağı Fir (Abies equitrojani Aschers et. Sint.) populations sampled from Kazdağları, Technical Bulletin No: 3, Forest Tree Seeds and Tree Breeding Research Directorate, Ankara, Turkey, $31 \mathrm{p}$.

Walther, G. R., E. Post, P. Convey, A. Menzel, C. Parmesan, T. J. C. Beebee, J. M. Fromentin, O. Hoegh-GuldBERG and F. BAIRLEIN (2002): Ecological responses to recent climate change. Nature 416: 389-395.

Wang, T., A. Hamann, A. Yanchuk, G. A. O'Neill and S. N. AITKEN (2006): Use of response functions in selecting lodgepole pine populations for future climates. Global Change Biology 12: 2404-2416.

White, T. (1996): Genetic parameter estimates and breeding value predictions: issues and implications in tree improvement programs, pp. 110-117. In: Tree improvement for sustainable tropical forestry, edited by M. J. DiETERS, C. E. HARWOOD and S. U. WALKER, Queensland Forestry Research Institute, Gympie.

\title{
Microsatellite Based Paternity Analysis in a Clonal Eucalyptus nitens Seed Orchard
}

\author{
By C. Grosser ${ }^{1), 2)}$, B. M. Potts ${ }^{1)}$ and R. E. Vaillancourt ${ }^{1), 3)}$
}

(Received $3^{\text {rd }}$ October 2008)

\begin{abstract}
Microsatellite markers were used to determine paternity in 473 open-pollinated progenies from a clonal Eucalyptus nitens seed orchard of 50 trees from 12 different genotypes. The outcrossing rate in this orchard was high, averaging 0.85 (weighted by capsule crop) but variable between trees (ranging from 0.6-1.0). Paternal contribution of each genotype to the open-pollinated seed crop was predicted by the size of the flower crop of

\footnotetext{
1) School of Plant Science and Cooperative Research Centre for Forestry, University of Tasmania, Private Bag 55, Hobart Tasmania 7001 Australia.

2) Forensic Science Service Tasmania. 20 St Johns Avenue, New Town Tasmania 7008 Australia.

3) Corresponding author: RENÉ E. VAILLANCOURT. E-Mail: R.Vaillancourt@utas.edu.au
}

each genotype $(\mathrm{r}=0.76)$, but not the number of ramets. While the detectable contamination in this orchard is relatively low $(4.5 \%)$, it is atypical when compared to other published estimates in eucalypt seed orchards suggesting that with suitable buffering low levels of contamination can be achieved.

Key words: Outcrossing rate; selfing; eucalypt genetics.

\section{Introduction}

Eucalyptus nitens (Deane \& Maiden) Maiden is a tall forest tree occurring naturally in disjunct populations on the southern side of the Great Dividing Range along the east coast of Australia (BROOKER and KLEINIG, 1983; HAMilton et al., 2008). This species has demonstrated a number of characteristics of value to the forest industry, 
such as good form, fine branches, frost resistance, good pulping and solid wood properties (HAMILTON et al., 2008). Due to these characteristics $E$. nitens has been established as a short rotation plantation species around the world (South Africa, Australia, New Zealand, Chile, Portugal, Spain and China; TiBBits et al., 1997). It is the second most planted hardwood in Australia with the area of plantations estimated at 142.000 ha in 2005 (PARsons et al., 2006).

While plantations of some eucalypt species, particularly those of the tropics and subtropics, are established from clones derived from hardwood cuttings (PoTTs, 2004), E. nitens is notoriously difficult to propagate from hardwood cuttings and virtually all plantations are established from seed derived seedlings (TIBBITs et al., 1997; GRIFFIN, 2001). In eucalypts there are three main sources of improved seed (in order of improvement): open-pollinated seed from the best native stands identified following provenance testing; open-pollinated seed from selected genotypes established together, derived from either culled progeny trials (seedling seed orchard, SSO) or clonally replicated genotypes (clonal seed orchard, CSO); and controlled pollinated seed where selected genotypes are mated (ELDRIDGE et al., 1993). While there is some scope for control pollination in $E$. nitens (Tіввітs, 1989), the small size of the flowers makes this a costly and labour intensive proposal (WILliams et al., 1999; Venter and SILVLAL, 2007) and the techniques developed for the large-scale production of elite control pollinated seed from larger-flowered species such as E. globulus (HARBARD et al., 1999; PATterson et al., 2004) have not been successful with E. nitens (Williams et al., 1999; Venter and Silvlal, 2007). This has meant that the best improved seed for $E$. nitens plantation establishment in Australia (and countries with similar labour costs) is reliant upon openpollinated seed from seed orchards (TiBBITs et al., 1997; GrIfFIN, 2001; HAMILTON et al., 2008). However, openpollinated seed collected from seed orchards carries a number of concerns about genetic quality that need studying.

Eucalypts (including $E$. nitens) have a mixed-mating system, with wide variation in outcrossing rates between trees and species (PоTTS and WiLtshiRe, 1997; BYRNE, 2007). A mixed mating-system raises concerns over inbreeding depression in progeny derived from self pollination. Such inbreeding depression can have a severe effect on growth and survival in eucalypt species, including E. nitens (HARDNER and TibBITS, 1998). Eucalyptus nitens exhibits varying levels of self-incompatibility (Pound et al., 2003), and although the loss in productivity due to selfing may be significant to a forest grower, to date there has been only two reported estimates of outcrossing rate in $E$. nitens seed orchards, one a SSO in north-western Tasmania (0.75, MoNCUR et al., 1995), the other a CSO in New Zealand (0.87, GEA et al., 2007). In order to predict the genetic quality (or genetic gains) expected from seed crops derived from open-pollinated seed orchards comprising selections of known genetic worth (breeding value), it is necessary to predict, firstly the relative paternal contribution of the various trees in the seed orchard, secondly the level of inbreeding depression arising from self pollination, and thirdly, the level of contamination of the orchard by pollen of lower genetic worth. Eucalyptus nitens is pollinated by insects (HINGston et al., 2004) and its pollen is mainly deposited within short distances, however, it has the potential to move long distances (BARBOUR et al., 2005). Gene flow from native forest into $E$. nitens plantings (and also the contrary) has been demonstrated (BARBOUR et al., 2002). This highlights the risk of pollen contamination if inadequate buffers between orchard and cross compatible native or plantation eucalypts are used.

The present study used microsatellite paternity analysis to address issues of seed quality in open-pollinated seedlots from a clonal seed orchard of $E$. nitens. This seed orchard is relatively well isolated from con-specific sources of contaminating pollen as the closest $E$. nitens is a small planting $200 \mathrm{~m}$ west of the orchard, beyond which the nearest recorded incidence of $E$. nitens is over $20 \mathrm{~km}$ away. Microsatellites have been widely used in eucalypt population genetics (BYRNE, 2007) and recently in studies of Eucalyptus seed orchards (RUSSELL et al., 2001; Chaix et al., 2003; Patterson et al., 2004; GEA et al., 2007; RAO et al., 2008; JoNES et al., 2008), because they are highly polymorphic, and co-dominant. We specifically investigated: the degree of contamination, and the variation in outcrossing rates and paternal contribution between genotypes in the seed orchard.

\section{Material and Methods}

The Olinda Eucalyptus nitens grafted clonal seed orchard (42 kilometers east of Melbourne, established in 1981) used for this study covers 0.33 hectares, and originally contained 92 trees established at a spacing of $6 \times 6$ and $6 \times 7$ meters. The seed orchard was established on cleared agricultural land surrounded by E. obliqua and $E$. regnans forest which, because they belong to a different subgenus, are cross-incompatible with $E$. nitens (PotTs et al., 2003). This seed orchard is relatively well isolated from con-specific sources of contaminating pollen as the closest $E$. nitens is a small planting $200 \mathrm{~m}$ west of the orchard, beyond which the nearest recorded incidence of $E$. nitens is over $20 \mathrm{~km}$ away. The seed orchard was established from scions taken from selections made on the basis of volume production from three base population family trials of $E$. nitens. The orchard was later reduced to 50 trees of 10 genotypes due to natural attrition through graft union failure (fingerprinting later demonstrated that there was in fact 12 genotypes in the orchard). Each genotype had differing numbers of ramets due to variable graft survivorship and natural culling of the orchard (Table 1). As flowering occurred the year prior to sampling (1997/1998 season) we assumed that the size of the capsule crop at the time of sampling was correlated with the relative size of the flowering crop the previous year. The standing capsule crop resulting from the 1997/1998 flowering season was assessed in April 1999 using binoculars, through counts of the numbers of umbels (there are usually 7 flowers per umbel but some of these abort). The number of umbels per tree was scored on a logarithmic scale as follows: (0) no umbels; (1) 1-10 umbels; (2) 10-100; (3) $100-1000$; (4) 1000-10000; (5) 10000+. These repro- 
ductive scores were verified when trees were climbed to collect seed samples, as the on-ground assessment closely matched that observed by the tree climber. The standing capsule crop (from the 1997/1998 flowering season) on the trees in the Olinda seed orchard was quite high, with over half the trees carrying $10000+$ umbels. There were six trees with no capsules, and two of these were the sole representative of their genotype in the orchard (clones 173 and 473). The lack of capsules on these six trees suggests that they did not flower during the 1997-1998 season. A single ramet of each genotype was selected for study. Capsules were collected from the top three meters of each crown by a tree climber. A random sample of 60 seeds from each of these trees was germinated and grown in a glasshouse (except clone 201 where only 10 seed were available).

Fully expanded foliage from the current year's growth on each of the 50 trees in the orchard was collected for DNA extraction. DNA was extracted from the foliage sampled from the trees in the orchard, and the germinated seedlings using a CTAB protocol (DoYLE and DoYLE, 1990). DNA was successfully extracted from 473 seedlings. All trees in the orchard were fingerprinted using 20 EMBRA (BRONDANI et al., 1998) and 12 EMCRC (STEANE et al., 2001) microsatellite primers. Loci to screen the progeny were selected based on two main criteria: firstly, they had to provide a high level of exclusionary power assuming one known parent; and secondly, loci were required to amplify without ambiguity in the parental population. Although none of the microsatellite primers were developed for $E$. nitens (EMBRAs were developed in E. grandis and E. urophylla, while EMCRCs were developed in E. globulus) four loci could distinguish among all genotypes in the orchard (EMBRA 5 and 18, EMCRC 5 and 12), such that each clone had a unique multilocus microsatellite genotypes. PCR amplification was done as in BRONDANI et al. (1998) and STEANE et al. (2001), and fragment lengths were determined using electrophoretic separation on a denaturing polyacrylamide gel using the Gel-Scan 2000 real-time acrylamide gel system (Corbett Research) as described by Jones et al. (2002). Allele size was determined using the Gene Profiler ${ }^{\mathrm{TM}}$ software (Scanalytics, Inc.).

The selected loci were used to screen the seedlings and paternity was assigned using CERVUS 1.0 (MARSHALL et al., 1998), a likelihood-based parentage analysis software package for co-dominant loci. Allele frequencies were estimated using all genotyped trees (both parents and progeny as suggested by MARSHALL et al., 1998) and paternity was assigned at two confidence levels, $80 \%$ and 95. These confidence limits yielded differences in overall likelihood ratio scores between the most likely candidate parent and the second most likely candidate parent (Delta) of 1.01 and 2.54 respectively. All twelve clones in the orchard were assumed to be candidate males, however since we were not sure of the absence of contamination we assumed that $80 \%$ of all candidate males were included for the simulation within CERVUS. There was no missing data in the study. The error rate for the CERVUS analysis was set at 0.01. When all genotypes in the orchard could be excluded the progeny was deemed to result from contaminating pollen. The genotype of all progeny identified to be the result of selfing (within ramet or between ramets of the same genotype) or contamination, as well as some randomly chosen outcross progeny were checked manually to ensure that CERVUS was assigning paternity correctly. Outcrossing rate was calculated based on paternity assignment. For example, self seedlings were checked for the presence of non-maternal alleles while outcross progenies were checked for their match to the putative father. A chi-square contingency test (using Yates' Correction for Continuity) was used to test the differences in outcrossing rates between trees. The Pearson correlation between the paternal contribution of each clone and various factors was calculated using PROC CORR of SAS (SAS, 1997).

\section{Results and Discussion}

Fingerprinting of the Olinda seed orchard showed two errors in labeling of the 50 trees (equating to a $4 \%$ error rate). These trees possessed fingerprints which did not match other ramets of the same clone in the orchard, suggesting that they were either mislabeled ramets of a clone removed from the orchard through roguing or from rootstock domination of the scion material. Errors of this type are not uncommon when molecular data is used to verify clone or family identity (KEIL and GRIFFIN, 1994; VAILlANCOURT et al., 1998). These errors contributed two new genotypes into the seed orchard, giving a total of 12 genotypes. Across these 12 genotypes, the four loci selected for paternity assignment were all highly polymorphic, with 8-14 alleles identified per locus. These loci provided an exclusionary power of 0.991 assuming that the maternal genotype was known (MARSHALl et al., 1998). Two confidence levels were used to assign paternity in the orchard. At the $95 \%$ confidence level, 369 of the 473 progenies had their paternity assigned. When the confidence level was relaxed to $80 \%$ a further 92 progeny were matched to a candidate male clone. The remaining 12 progeny showed no maternal mismatches (between the progeny and the mother tree); however paternity could not be assigned due to multiple mismatches with all candidate male clones. These 12 progeny were deemed to be the result of contamination into the orchard from external pollen sources (Table 1).

The 12 progeny resulting from contamination into this orchard produced an estimated detectable contamination rate of $2.5 \%$ ( $4.5 \%$ when weighted by capsule crop assessed from the number of umbels per tree). However, this level is a minimal estimate of contamination as it does not account for cryptic gene flow from similar male genotypes outside of the seed orchard (SLAVOV et al., 2005). Allele sizes found in progeny resulting from contamination in our study were within the range of allele sizes found in the orchard. This coupled with the absence of any morphological abnormality in these seedlings indicates that contamination probably resulted from $E$. nitens plantations, as opposed to inter-specific hybridization. As all trees in the seed orchard were fingerprinted, mislabelling errors can be excluded as a source of contamination. The most likely source of contaminating pollen in our study was a small planting of 
Table 1. - Paternity of open-pollinated seedlots collected in an E. nitens clonal seed orchard. For each female, the table shows the proportion of seedlings attributed to each male genotype in the seed orchard (Paternal contribution). Following the female ID, the number of seedlings fingerprinted is indicated in parenthesis. Shaded cells indicate clonal selfing rates (as pollen could have originated from any ramet of the maternal clone). The total number of umbels of capsules was summed across all ramets of a clone.

\begin{tabular}{|c|c|c|c|c|c|c|c|c|c|c|c|c|c|c|c|}
\hline & \multicolumn{10}{|c|}{ Clone ID of male parent } & \multirow{2}{*}{$\begin{array}{c}\text { Number of } \\
\text { umbels }\end{array}$} & \multirow{2}{*}{$\begin{array}{l}\text { Number } \\
\text { of ramets }\end{array}$} & \multirow{2}{*}{$\begin{array}{c}\text { Contamination } \\
\text { rate }^{\mathrm{a}}\end{array}$} & \multirow{2}{*}{$\begin{array}{l}\text { Outcrossing } \\
\text { rate }^{\text {b }}\end{array}$} \\
\hline & & 001 & 151 & 155 & 168 & 183 & 185 & 201 & 206 & 506 & 207 & & & & \\
\hline \multirow{10}{*}{ 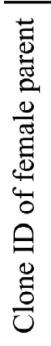 } & $001(52)$ & 0.16 & 0.16 & - & 0.11 & - & - & - & - & - & 0.58 & 70,000 & 7 & - & 0.84 \\
\hline & 151 (47) & - & - & - & 0.18 & 0.41 & 0.12 & - & 0.18 & - & 0.12 & 50,505 & 7 & - & 1.00 \\
\hline & $155(58)$ & 0.10 & - & 0.09 & 0.34 & 0.05 & - & 0.12 & - & 0.26 & - & 20,055 & 5 & 0.03 & 0.81 \\
\hline & $168(49)$ & 0.12 & 0.18 & 0.14 & - & - & 0.27 & - & 0.29 & - & - & 530 & 8 & - & 1.00 \\
\hline & $183(54)$ & - & 0.22 & - & - & 0.35 & 0.17 & - & 0.09 & 0.17 & - & 500 & 1 & - & 0.65 \\
\hline & $185(50)$ & - & 0.30 & - & 0.04 & 0.06 & 0.16 & - & 0.08 & - & 0.36 & 46,000 & 8 & - & 0.84 \\
\hline & 201 (10) & 0.20 & - & - & - & - & - & - & - & - & 0.60 & 5 & 2 & 0.20 & 1.00 \\
\hline & $206(51)$ & 0.12 & 0.29 & - & 0.18 & - & 0.12 & - & 0.10 & - & 0.14 & 45,000 & 5 & 0.06 & 0.90 \\
\hline & $506(50)$ & 0.33 & 0.26 & 0.12 & - & 0.02 & - & 0.04 & - & 0.14 & - & 10,000 & 1 & 0.09 & 0.86 \\
\hline & 207 (52) & 0.30 & 0.06 & - & 0.06 & 0.09 & - & - & 0.09 & - & 0.40 & 40,000 & 4 & - & 0.60 \\
\hline & $\begin{array}{l}\text { Paternal } \\
\text { ontribution }\end{array}$ & 0.13 & 0.16 & 0.04 & 0.10 & 0.11 & 0.09 & 0.02 & 0.09 & 0.07 & 0.19 & & & & - \\
\hline
\end{tabular}

a Contamination indicates that all clones in the orchard could be excluded.

b The outcrossing rate was determined where the male parent was of a different clone to the maternal parent.

- Indicates zero observations.

$E$. nitens $200 \mathrm{~m}$ west of the orchard, beyond which the nearest recorded incidence of $E$. nitens is over $20 \mathrm{~km}$ away. This detectable contamination, although small, highlights the potential for eucalypt pollen to travel significant distances (e.g. BARBOUR et al., 2002; BYRNE et al., 2008).

While the contamination in our orchard is relatively low, this is atypical when compared with other reports, and it is clear that contamination of seed orchards by unimproved material can be a significant issue which requires better consideration when placing seed orchards in forested landscapes (ELDRIDGE et al., 1993). For example, CHAIx et al. (2003) found a high contamination rate $(39 \%)$ in an $E$. grandis seed orchard in Madagascar, seemingly because of the small size of the orchard. Another study of an E. grandis seed orchard, this time in Australia, also found a high rate $(46 \%)$ of contamination (JONES et al., 2008). Similarly, RAO et al. (2008) found relatively high levels of contamination in an E. globulus seed orchard in Victoria (Australia) (17.6\%) from neighbouring E. globulus plantations, presumably because of the small size of the seed orchard and low levels of flowering. Two isozyme based studies of mixed clonal orchards of E. grandis and E. urophylla in Brazil reported contamination rates into these orchards of $14.2 \%$ (with a $400 \mathrm{~m}$ buffer of native tropical forest; CAMPINHOS et al., 1998) and $2.8 \%$ respectively (with an $800 \mathrm{~m}$ buffer of native tropical forest; JUNGHANS et al., 1998). The estimates of contamination are likely to be conservative as contamination was assumed only when allozymes not found amongst the clones in the orchard were identified in the progeny and cryptic gene flow is likely to be higher than with microsatellite markers (BYRNE, 2007). Buffers of synchronously flowering species are clearly one option for reducing contamination of seed orchards. Studies of insect pollinated species suggest that the best orchard buffer will be a species that flowers synchronously with the seed orchard (STANILAND et al., 2000), attracts the same pollinators, and cannot hybridize with the species in the seed orchard. Within Eucalyptus there is little barrier to hybridization between species of the same section, though it may be possible to exploit reproductive barriers between subgenera or sections for isolation purposes (GRIFFIN et al., 1988).

The average outcrossing rate for the orchard, 0.88 , was derived from Table 1, and this figure decreased to 0.85 when weighted by the capsule output (as estimated from the number of umbels) per genotype (Table 1) across the orchard. These estimates are in the upper range for outcrossing found in other mass flowering eucalypts (PotTs and Wiltshire, 1997; BYRne, 2007), and are consistent with earlier estimates of outcrossing in this species (GEA et al., 2007; MoNCUR et al., 1995). However, the outcrossing rates for the ten trees studied varied from 0.60 to 1.00 (Table 1 ). The chi-square contingency test showed that the differences between clones was highly significant $\left(\mathrm{P}\left\{\chi^{2}{ }_{9}=331.2\right\}<0.001\right)$. Assuming the observed variation in outcrossing rates in the 10 trees studied is stable (e.g. McGowen et al., 2004), there is potential to minimise the impact of selfing by targeting seed collection from trees with higher outcrossing rates.

The genetic worth of seed from a tree growing in an open-pollinated seed orchard will be mainly a function of (i) the level of inbreeding depression from selfing and biparental inbreeding, (ii) the relative male contribution to the outcrosses , and (iii) the breeding value of the partents. A knowledge of the levels of inbreeding rates and relative male contribution to the outcrosses can only be obtained from molecular studies. In the present study, male contributions differ markedly between different genotypes. For example, clone 201 sired $2 \%$ of all seedlings whereas clone 207 sired $19 \%$ of all seedlings assayed. The male contribution of the genotypes (clone) was not correlated with the number of ramets in the orchard for each genotype (Pearson correlation coefficient $\mathrm{n}=12, \mathrm{r}=0.54, \mathrm{P}>0.05)$. However, with knowledge of the reproductive output this male contribution could be predicted. There was a significant correlation 
between total number of umbels observed per genotype and the relative contribution of each genotype $(n=12$, $\mathrm{r}=0.76, \mathrm{P}<0.01$; Table 1 ). These results suggest that as more effort is expended in assessing the flower output of each tree in the orchard, a better estimate of the paternal contribution will be achieved. However, there is still a portion of the variation not explained by the correlation with our estimate of the flower crop. This may be due to the small sample sizes in this study which was limited by the number of clones in the orchard or the use of the umbel score as an estimate of flower crop. Furthermore, factors other than the reproductive output of the trees, such as flowering synchrony, self incompatibility and distance between mates, may play an important role in determining the likelihood of mating between two trees (SEDGLEY and GRIFFIN, 1989; GRIFFIn, 1990; Pound et al., 2003; PATterson et al.,, 2004).

\section{Acknowledgements}

This project was funded by an Australian Research Council SPIRT grant (C19906699). The authors would also like to thank Mr. MARTIN LAVERY of Arianda Pty Ltd for expert technical assistance, Silvagene Pty Ltd, and Mr. IAN BAIL for providing access to the study site.

\section{References}

Barbour, R. C., B. M. Potts, R. E. Vaillancourt, W. N. TibBits and R. J. E. Wiltshire (2002): Gene flow between introduced and native Eucalyptus species. New Forest 23: 177-191.

Barbour, R. C., B. M. Potts and R. E. Vaillancourt (2005): Pollen dispersal from exotic eucalypt plantations. Conservation Genetics 6: 253-257.

BRONDANi, R. P. V., C. BRONDANI, R. TARCHINI and D. GRATTAPAGLIA (1998): Development, characterization and mapping of microsatellite markers in Eucalyptus grandis and E. urophylla. Theoretical and Applied Genetics 97: 816-827.

Brooker, M. I. H. and D. A. KLeinig (1983): Field Guide to Eucalypts (volume 1), Inkata Press, Melbourne, Australia.

BYRne, M. (2007): Phylogeny, diversity and evolution of eucalypts. In: Plant Genome: Biodiversity and Evolution. (A. K. Sharma and A. Sharma Eds). Science Publishers.

Byrne, M., C. P. Elliott, C. J. Yates and D. J. Coates (2008): Maintenance of high pollen dispersal in Eucalyptus wandoo, a dominant tree of the fragmented agricultural region of Western Asutralia. Conservation Genetics 9: 97-105.

Campinhos, E. N., I. Peters-Robinson, F. L. Bertolucci and A. C. AlfenAs (1998): Interspecific hybridization and inbreeding effect in seed from a Eucalyptus grandis $\mathrm{x}$ E. urophylla clonal orchard in Brazil. Genetics and Molecular Biology 21: 369-374.

Chaix, G., S. Gerber, V. Razafimaharo, P. Vigneron, D. Verhaegen and S. HAMON (2003): Gene flow estimation with microsatellites in a Malagasy seed orchard of Eucalyptus grandis. Theoretical and Applied Genetics 107: 705-712.

Doyle, J. J. and J. L. Doyle (1990): Isolation of plant DNA from fresh tissue. Focus 12: 13-15.
ElDRIDGE, K., J. DAVIDSON, C. HARWOOD and G. VAN WyK (1993): Eucalypt Domestication and Breeding. Oxford University Press, New York.

Gea, L. D., R. McConnochie and S. Wynyard (2007): Parental reconstruction for breeding, deployment, and seed-orchard management of Eucalyptus nitens. New Zealand Journal of Forestry Science 37: 23-36.

GRIFFIN, A. R. (1990): Effects of inbreeding on growth of forest trees and implication for management of seed supplies for plantation programmes. In: Reproductive Ecology of Tropical Forest Plants. (Eds K. S. BAwA and M. HADLEY) pp. 355-372. (UNESCO and The Parthenon Publishing Group: Paris, France).

GRIFFIN, A. R. (2001): Deployment decisions - capturing the benefits of tree improvement with clones and seedlings. In: Proceedings of the IUFRO conference Developing the Eucalypt of the Future 10-15 Sept. 2001, Valdivia, Chile. CD-Rom communication. (Instituto Forestal [INFOR], Chile).

Griffin, A. R., I. P. Burgess and L. Wolf (1988): Patterns of natural and manipulated hybridisation in the genus Eucalyptus L'Herit. - a review. Australian Journal of Botany 36: 41-66.

Harbard, J. L., A. R. GRIFFin and J. Espejo (1999): Mass controlled pollination of Eucalyptus globulus: a practical reality. Canadian Journal of Forest Research 29: 1457-1463.

Hamilton, M. G., K. Joyce, D. Williams, G. W. DutkowSKI and B. M. POTTS (2008): Genetic improvement of Eucalyptus nitens in Australia. Australian Forestry 71: 82-93.

HARDNeR, C. M. and W. N. TibBits (1998): Inbreeding depression for growth and fecundity traits in Eucalyptus nitens. Forest Genetics 5: 11-20.

Hingston, A. B., P. B. McQuillan and B. M. PotTs (2004): Pollinators in seed orchards of Eucalyptus nitens (Myrtaceae). Australian Journal of Botany 52: 209-222.

Jones, R. C., D. A. Steane, B. M. Potts, R. E. VaillanCOURT (2002): Microsatellite and morphological analysis of Eucalyptus globulus populations. Canadian Journal of Forest Research: 59-66.

Jones, M. E., M. Shepherd, R. Henry and A. Delves (2008): Pollen flow in Eucalyptus grandis determined by paternity analysis using microsatellite markers. Tree Genetics and Genomes 4: 37-47.

Junghans, T. G., I. Peters-Robinson, F. L. Bertolucci and A. C. Alfenas (1998): The use of self-incompatibility in the production of hybrid Eucalyptus seed by Aracruz Celulose in Brazil. Genetics and Molecular Biology 21: 375-379.

KeIL, M. and A. R. GrIfFIN (1994): Use of Random Amplified Polymorphic DNA (RAPD) Markers in the discrimination and verification of genotypes in Eucalyptus. Theoretical and Applied Genetics 89: 442-450.

Marshall, T. C., J. Slate, L. E. B. KruUk and J. M. PemBERTON (1998): Statistical confidence for likelihoodbased paternity inference in natural populations. Molecular Ecology 7: 639-655.

McGowen, M. H., D. R. Williams, B. M. Potts and R. E. VAILLANCOURT (2004): Stability of outcrossing rates in Eucalyptus globulus seedlots. Silvae Genetica 53: 42-44.

Moncur, M. W., A. Mitchell, Y. Fripp and G. J. KleinSCHMIDT (1995): The role of honey bees (Apis mellifera) in eucalypt plantation forestry. Commonwealth Forestry Review 74: 350-354. 
Parsons, M., M. Gavran and J. Davidson (2006): Australia's plantations 2006 - National report. Australian Government Department of Agriculture, Fisheries and Forestry. http://www.daff.gov.au/.

Patterson, B., P. Gore, B. M. Potts, R. E. Vaillancourt (2004): Advances in pollination techniques for largescale seed production in Eucalyptus globulus. Australian Journal of Botany 52: 781-788.

PotTs, B. M. (2004): Genetic improvement of eucalypts. In: Encyclopedia of Forest Science (eds. Evans, J., BuRLEY, J. and YoungQuisT, J.) pp. 1480-1490. (Elsevier Science, Oxford).

Potts, B. M. and R. J. E. Wiltshire (1997): Eucalypt genetics and genecology. In: Eucalypt Ecology: Individuals to Ecosystems. Edited by J. WILliAMs and J. WoInARSKI, Cambridge University Press, Cambridge, UK. pp. 56-91.

Potts, B. M., R. C. Barbour, A. B. Hingston and R. E. VAILlancourt (2003). Turner Review No. 6. Genetic pollution of native eucalypt gene pools - identifying the risks. Australian Journal of Botany 51: 1-25.

Pound, L. M., M. A. B. Wallworth, B. M. Potts and M. SedGley (2003): Pollen tube growth and early ovule development following self- and cross-pollination of Eucalyptus nitens. Sexual Plant Reproduction 16: 59-69.

RaO, H., B. Patterson, B. M. Potts and R. E. VaillanCOURT (2008): A microsatellite study of outcrossing rates and contamination in a Eucalyptus globulus breeding arboretum. Journal of Forestry Research 19: 136-140.

Russell, J., D. Marshall, A. R. Griffin, J. Harbard and W. Powell (2001): Gene flow in South American Eucalyptus grandis and Eucalyptus globulus seed ochards. In: Proceedings of the IUFRO conference Developing the Eucalypt of the Future 10-15 Sept. 2001, Valdivia, Chile. pp. 149-150.

SedGley, M. and A. R. GRIFFIN (1989): Sexual reproduction of tree crops. (Academic Press: London).
SAS INSTITUTE (1997): SAS/STAT software: changes and enhancements through Release 6.12. SAS Institute, Cary, N. C.

Slavov, G. T., G. T. Howe, A. V. Gyaourova, D. S. Birkes and W. T. ADAMS (2005). Estimating pollen flow using SSR markers and paternity exclusion: Accounting for mistyping. Molecular Ecology 14: 3109-3121.

Staniland, B. K., P. B. E. McVetty, L. F. Friesen, S. Yarrow, G. Fressinet and M. Fressinet (2000): Effectiveness of border areas in confining the spread of transgenic Brassica napus pollen. Canadian Journal of Plant Science 80: 521-526.

Steane, D. A., R. E. Vaillancourt, J. Russell, W. Powell, D. MARshall and B. M. PotTs (2001): Development and characterisation of microsatellite loci in Eucalyptus globulus (Myrtaceae). Silvae Genetica 50: 89-91.

TibBits, W. N. (1989): Controlled pollination studies with shining gum (Eucalyptus nitens (Deane \& Maiden) Maiden). Forestry 62: 111-126.

TibBits, W. N., D. B. Boomsma and S. JARvis (1997): Distribution, biology, genetics, and improvement programs for Eucalyptus globulus and E. nitens around the world. In: Proceedings of the $24^{\text {th }}$ Biennial Southern Tree Improvement Conference, June 9-12 1997. Edited by T. White, D. Huber and G. Powell. Southern Tree Improvement Committee, Orlando, Florida. pp. 81-95.

VAILlAnCOURT, R. E., S. SKaBo and P. L. Gore (1998): Fingerprinting for quality control in breeding and deployment. Australian Forestry 61: 207-210.

VENTER, H. and A. Silvlal (2007): Fluorescence microscopy study of the effect of TVP, OSP and AIP cross pollination techniques on successful pollen germination on the stigma. In: Proc. IUFRO Working group 2.08.03 Eucalypts and diversity: balancing productivity and sustainability Durban, South Africa, 22-26 October 2007.

Williams, D. R., B. M. Potts and P. G. Black (1999): A single visit pollination method for Eucalyptus globulus. Australian Forestry 62: 346-352.

\title{
Use of Microsatellite Markers in an American Beech (Fagus grandifolia) Population and Paternity Testing
}

\author{
By J. L. KOCH ${ }^{\left.1),{ }^{*}\right)}$, D. W. CAREY ${ }^{1)}$ and M. E. MASON ${ }^{2)}$
}

(Received 22 $2^{\text {nd }}$ October 2008)

\begin{abstract}
Cross-species amplification of six microsatellite markers from European beech (Fagus sylvatica Linn) and nine markers from Japanese beech (Fagus crenata

1) U.S. Forest Service, Northern Research Station, 359 Main Rd., Delaware, $\mathrm{OH} 43015$, USA.

2) The Ohio State University, Ohio Agricultural Research and Development Center, Department of Entomology, 1680 Madison Ave, Wooster, OH 44691, USA.

*) Corresponding author: Jennifer L. Koch. Tel. (740) 368-0188; Fax (740) 369-2601. E-Mail: jkoch@fs.fed.us
\end{abstract}

Blume) was tested in American beech (Fagus grandifolia Ehrh.). Three microsatellites from each species were successfully adapted for use in American beech and were found to be highly polymorphic, with 4-22 alleles at each locus and an expected heterozygosity value of 0.291 to 0.913 . Twenty-five trees (including two clonal clusters) from a mature stand were sampled and genotyped to compute population statistics. No linkage disequilibrium between pairs of loci was detected, and the marker loci indicated that the population is at HardyWeinberg equilibrium. The markers were also used to genotype two full-sibling families consisting of a com- 